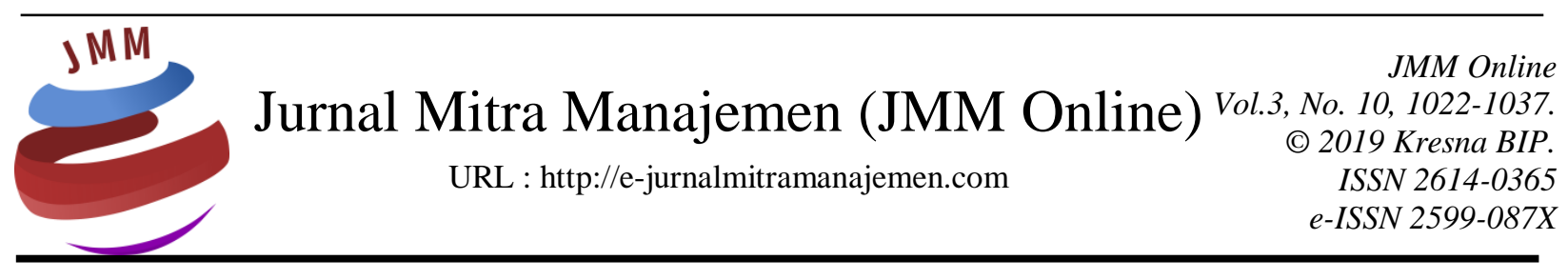

\title{
PENGARUH PENERAPAN SISTEM ADMINISTRASI PERPAJAKAN MODERN DAN KESADARAN WAJIB PAJAK TERHADAP KEPATUHAN WAJIB PAJAK ORANG PRIBADI (Studi Kasus di Kantor PT Bali Jaya Transindo Surabaya)
}

\author{
Rika Indah Sasmita \\ Universitas Wijaya Putra Surabaya
}

\section{INFORMASI ARTIKEL}

Dikirim : 23 Oktober 2019

Revisi pertama : 26 Oktober 2019

Diterima : 28 Oktober 2019

Tersedia online : 05 November 2019

Kata Kunci : Sistem Administrasi Perpajakan Modern, Kesadaran Wajib Pajak, Kepatuhan Wajib Pajak

Email : rikaindasasmita57@gmail.com

\section{ABSTRAK}

Penelitian ini bertujuan untuk menguji dan menganalisis Pengaruh Penerapan Sistem Administrasi Perpajakan Modern, dan Kesadaran Wajib Pajak Terhadap Kepatuhan Wajib Pajak Orang Pribadi di Kantor PT Bali Jaya Transindo Surabaya. Jumlah Responden dalam penelitian ini adalah sebanyak 32 orang.

Program dan kegiatan sistem administrasi perpajakan modern terhadap kepatuhan wajib pajak pada dasarnya meliputi tax service dan tax law enforcement akan lebih banyak mempengaruhi tingkat kepatuhan wajib pajak. Oleh karena itu tingkat pelayanan masyarakat dan kesadaran wajib pajak menjadi salah satu poin penting dari keseluruhan penelitian sistem administrasi perpajakan modern ini.

Metode penelitian yang digunakan adalah metode deskriptif asosiatif. Data yang digunakan adalah data primer berupa kuesioner yang dibagikan menggunakan google form. Hasil penelitian secara deskriptif menunjukkan bahwa sistem administrasi perpajakan modern dan kesadaran wajib pajak terhadap kepatuhan wajib pajak orang pribadi di Kantor PT Bali Jaya Transindo Surabaya termasuk dalam kategori baik. Hasil pengujian Hipotesis secara parsial membuktikan bahwa sistem administrasi perpajakan modern tidak berpengaruh signifikan terhadap Kepatuhan wajib pajak sedangkan secara simultan untuk Kesadaran wajib pajak berpengaruh signifikan terhadap Kepatuhan wajib pajak dengan nilai koefisien determinasi sebesar 82,4\% sedangkan sisanya sebesar 17,6 dipengaruhi oleh faktorfaktor lain yang tidak diteliti. 


\section{PENDAHULUAN \\ Latar Belakang}

Pajak merupakan salah satu sumber pendapatan negara sekaligus sektor yang potensial dalam membiayai dan menyukseskan pembangunan nasional. Dana yang dibutuhkan pemerintah akan meningkat seiring dengan adanya peningkatan kebutuhan pembangunan, maka peran masyarakat dalam memenuhi kewajibannya dalam membayar pajak akan dapat membantu berjalannya pertumbuhan negara.

Undang-Undang No. 28 Tahun 2009 mendefinisikan pajak sebagai kontribusi wajib pajak kepada negara yang terutang oleh orang pribadi atau badan yang bersifat memaksa berdasarkan undang-undang. Bagi Indonesia, penerimaan pajak sangat besar peranannya dalam mengamankan anggaran negara dalam APBN pada setiap tahunnya.

Pajak adalah suatu kewajiban warga negara yang merupakan bentuk wujud pengabdian terhadap negara yang timbal baliknya tidak bisa dirasakan secara langsung oleh wajib pajak. Banyak manfaat yang dapat dirasakan oleh masyarakat mengenai peranan pajak dalam pembangunan contohnya adalah fasilitas pendidikan, fasilitas transportasi, fasilitas kesehatan, sarana, prasarana umum dan manfaat ini dapat dirasakan secara langsung dan tidak langsung. Oleh karena itu setiap wajib pajak dituntut untuk selalu melaporkan dan membayarkan pajaknya secara tepat waktu untuk meningkatkan penerimaan pajak.

Kepatuhan pajak juga selalu dikaitkan dengan reformasi perpajakan, dengan adanya penerapan sistem administrasi perpajakan modern yang transparan dan akuntabel dengan memanfaatkan sistem teknologi informasi yang handal dan terkini menjadikan kualitas sistem pelayanan perpajakan menjadi lebih baik dan memudahkan wajib pajak, sehingga di harapkan mampu meningkatkan kepatuhan wajib pajak untuk memenuhi kewajiban perpajakannya.

Menurut Arini \& Isharijadi (2015) tujuan dari penerapan sistem administrasi perpajakan modern adalah untuk tercapainya sukarela yang tinggi, tercapainya tingkat kepercayaan masyarakat yang tinggi dan mengedepankan aspek pelayanan yang tinggi. Menurut Astana \& Merkusiwati (2017) selain sistem administrasi modern dan kesadaran wajib pajak juga merupakan salah satu faktor yang mempengaruhi tingkat kepatuhan wajib pajak.

Menurut Muliari (dalam Astana \& Merkusiwati (2017)) kesadaran wajib pajak merupakan sebuah itikad baik seseorang untuk memenuhi kewajiban membayar pajak secara sukarela. Semakin tinggi tingkat kesadaran wajib pajak, maka pemahaman dan pelaksanaan kewajiban perpajakan semakin baik sehingga dapat meningkatkan kepatuhan wajib pajak.

Konsep sistem administrasi modern dalam perpajakan pada prinsipnya merupakan perubahan pada sistem administrasi perpajakan yang dapat mengubah pola pikir dan perilaku aparat serta tata nilai organisasi sehingga dapat menjadikan Direktorat Jenderal Pajak (DJP) menjadi suatu institusi yang profesional dengan citra yang baik di masyarakat.

Konsep dibentuknya Sistem Administrasi Perpajakan Modern adalah pelayanan prima, pengawasan intensif dan pelaksanaan Good Governance. Salah satunya adalah dengan diberlakukannya Self Assessment System, Sistem ini diberlakukan sejak terjadinya reformasi kebijakan perpajakan pada tahun 1983 dengan diterbitkannya 
seperangkat peraturan perundang-undangan dibidang perpajakan yang menggantikan perundang-undangan yang dibuat oleh Pemerintah Kolonial Belanda.

Self Assessment System adalah suatu sistem pemungutan pajak dimana wajib pajak diberikan wewenang untuk menghitung sendiri besarnya pajak yang harus dibayar atau terutang (Masdiasmo, 2013:7). Dalam sistem ini wajib pajak diberi tanggung jawab untuk menghitung, membayar, dan melaporkan sendiri besaran pajak yang harus dibayar sehingga penentuan besarnya pajak yang terutang dipercayakan pada wajib pajak sendiri melalui Surat Pemberitahuan (SPT) yang disampaikannya. Self Assessment System juga menuntut adanya perubahan sikap (kesadaran) warga masyarakat wajib pajak untuk membayar pajaknya (Waluyo, 2013).

Permasalahan yang sering muncul dalam kewajiban pajak adalah tingkat kepatuhan wajib pajak yang merupakan masalah dari penerapan Self Assessment System. Kepatuhan wajib pajak yang rendah itu dikarenakan masyarakat selaku wajib pajak lupa, atau bahkan mungkin mengabaikan kewajibannya untuk membayar pajak, khususnya pajak penghasilan orang pribadi. Semakin tinggi tingkat kepatuhan wajib pajak maka akan semakin tinggi pula penerimaan pajak negara. Sebaliknya jika semakin rendah tingkat kepatuhan wajib pajak maka akan semakin rendah pula anggaran penerimaan negara. Untuk itu perlu dikaji lebih dalam lagi mengenai hal-hal yang dapat mempengaruhi tingkat kepatuhan wajib pajak. Banyak faktor yang dapat mempengaruhi tingkat kepatuhan wajib pajak, sistem administrasi perpajakan modern merupakan salah satu faktor yang dapat meningkatkan kepatuhan wajib pajak (Rahmawati, 2014).

Menurut Rahayu dan Lingga (2009), program dan kegiatan reformasi administrasi perpajakan diwujudkan dalam penerapan sistem administrasi perpajakan modern yang memiliki ciri khusus antara lain struktur organisasi berdasarkan fungsi, perbaikan pelayanan bagi setiap wajib pajak dalam pembentukan account representative dan complaint center untuk menampung pendapat, kritikan, maupun saran dari wajib pajak. Selain itu, sistem administrasi perpajakan modern juga mencakup kemajuan teknologi terbaru diantaranya melalui pengembangan Sistem Informasi Perpajakan (SIP) yang semula berdasarkan pendekatan fungsi menjadi Sistem Administrasi Perpajakan Terpadu (SAPT) yang dikendaliikan oleh Case Management Sistem dalam Workflow System dengan berbagai modul otomatisasi kantor serta berbagai pelayanan berbasis $e$-system seperti $e$-SPT, e-Filling, e-Payment, Taxpayer's Account, e-Registration, dan e-Counceling.

Dengan diterapkannya sistem administrasi perpajakan modern dapat meningkatkan pelayanan perpajakan kepada masyarakat wajib pajak sehingga diharapkan dapat mendorong tingkat kepatuhan wajib pajak. Tingkat kepatuhan wajib pajak yang tinggi tentunya juga akan berdampak pada peningkatan jumlah pendapatan pajak, sehingga hal ini pun dapat mengoptimalkan jumlah penerimaan APBN guna membantu pemerintah untuk membiayai pembangunan nasional.

Berdasarkan latar belakang masalah diatas peneliti merasa tertarik untuk mengetahui lebih lanjut tentang masalah tersebut, sehingga untuk penelitian kali ini peneliti mengambil judul "Pengaruh Penerapan Sistem Administrasi Perpajakan Modern dan Kesadaran Wajib Pajak Terhadap Kepatuhan Wajib Pajak Orang Pribadi Studi Kasus di Kantor PT Bali Jaya Transindo Surabaya". 


\section{Rumusan Masalah}

Berdasarkan latar belakang yang telah diuraikan diatas, maka rumusan masalah yang dapat di identifikasi dalam penelitian ini adalah :

1. Apakah sistem administrasi perpajakan modern berpengaruh terhadap kepatuhan wajib pajak di PT Bali Jaya Transindo Surabaya?

2. Apakah kesadaran wajib pajak berpengaruh terhadap kepatuhan wajib pajak di PT Bali Jaya Transindo Surabaya?

3. Apakah sistem administrasi perpajakan modern dan kesadaran wajib pajak secara simultan berpengaruh terhadap kepatuhan wajib pajak di PT Bali Jaya Transindo?

\section{Tujuan Penelitian}

Berdasarkan Rumusan Masalah diatas, penelitian ini bertujuan untuk menguji :

1. Pengaruh sistem administrasi perpajakan modern terhadap kepatuhan wajib pajak di PT Bali Jaya Transindo Surabaya.

2. Pengaruh kesadaran wajib pajak terhadap kepatuhan wajib pajak di PT Bali Jaya Transindo Surabaya.

3. Pengaruh sistem administrasi perpajakan modern dan kesadaran wajib pajak secara simultan berpengaruh terhadap kepatuhan wajib pajak di PT Bali Jaya Transindo?

\section{KAJIAN PUSTAKA \\ Pengertian Pajak}

Pajak menurut Pasal 1 Undang-undang No. 28 Tahun 2009 mendefinisikan pajak sebagai kontribusi Wajib Pajak kepada negara yang terutang oleh orang pribadi atau badan yang bersifat memaksa berdasarkan undang-undang, dengan tidak mendapat timbal balik secara langsung dan digunakan untuk keperluan negara bagi sebesar-besarnya untuk kemakmuran rakyat.

Beberapa pendapat menurut para ahli tentang pengertian pajak antara lain : Menurut Rochmat Soemitro dalam Mardiasmo, (2016:3) : "Pajak adalah iuran rakyat kepada kas negara berdasarkan Undang-undang dengan tidak mendapat jasa timbal (kontra Prestasi) yang langsung dapat ditunjukkan dan yang digunakan untuk membayar pengeluaran umum". Menurut Prof. Dr. P.J.A. Adriani dalam Thomas Sumarsan (2013:3) : Pajak adalah iuran kepada negara (dapat dipaksakan) yang terutang oleh yang wajib pajak yang membayarnya menurut peraturan-peraturan, dengan tidak mendapat kontra prestasi kembali, yang langsung dapat ditunjuk, dan gunanya adalah untuk membiayai pengeluaran-pengeluaran umum berhubungan dengan tugas negara yang menyelenggarakan pemerintahan.

Menurut Prof. Dr. Djajadiningrat dalam Siti Resmi (2013:2) : Pajak adalah suatu kewajiban untuk menyerahkan sebagian kekayaan negara karena suatu keadaan, kejadian, perbuatan yang memberikan kedudukan tertentu. Pungutan tersebut bukan sebagai hukuman, tetapi menurut peraturan-peraturan yang telah ditetapkan pemerintah hal ini bersifat dapat dipaksakan. Untuk itu, tidak ada jasa balik dari negara secara langsung.

Dari beberapa pengertian menurut para ahli diatas, maka dapat disimpulkan bahwa pajak merupakan suatu kewajiban yang bersifat memaksa bagi wajib pajak orang pribadi dan badan untuk dapat memberikan iuran pada kas negara berdasarkan 
peraturan perundang-undangan yang diberlakukan oleh negara dan hanya digunakan untuk menutup anggaran pengeluaran umum negara.

Menurut Mardiasmo (2016:3) dari definisi tersebut, dapat disimpulkan bahwa pajak memiliki unsur-unsur :

1. Iuran dari rakyat kepada negara. Yang berhak memungut pajak hanyalah DJP negara.

2. Berdasarkan undang-undang, Pajak dipungut berdasarkan atau dengan kekuatan undang-undang serta aturan pelaksanaannya.

3. Tanpa jasa timbal atau kontraprestasi dari negara secara langsung.

4. Digunakan untuk membiayai anggaran pengeluaran negara, yakni pengeluaranpengeluaran yang bermanfaat bagi masyarakat / warga negara secara luas.

\section{Fungsi Pajak}

Pajak mempunyai peranan yang sangat penting dalam kehidupan bernegara, khususnya didalam pelaksanaan pembangunan karena pajak merupakan sumber pendapatan negara untuk membiayai semua pengeluaran pembangunan.

Menurut Mardiasmo (2013:1), terdapat dua fungsi pajak yaitu :

1. Fungsi Penerimaan (budgetair)

Pajak merupakan salah satu sumber dana bagi pemerintah untuk membiayai pengeluran-pengeluaran pemerintah.

2. Fungsi Pengatur (regularend)

Pajak merupakan alat untuk pengatur atau melaksanakan kebijakan pemerintah dalam bidang sosial dan ekonomi serta mencapai tujuan-tujuan tertentu di luar bidang keuangan.

\section{Official Assesment System}

Adalah sistem pemungutan pajak dimana jumlah pajak yang harus dilunasi atau terutang oleh Wajib Pajak dihitung dan ditetapkan oleh fiskus/aparatur pajak. Jadi, dalam sistem ini Wajib Pajak bersifat pasif sedangkan Fiskus bersifat aktif. Menurut sistem ini utang pajak timbul apabila telah ada ketetapan pajak dari pihak Fiskus. Dengan demikian jika dihubungkan dengan ajaran timbulnya utang pajak maka System Official Assesment sesuai dengan timbulnya utang pajak menurut ajaran formal, yang artinya utang pajak akan timbul apabila sudah ada ketetapan hasil pajak dari pihak Fiskus.

\section{Sistem Administrasi Perpajakan Modern}

Pandiangan (2013:43) mendefinisikan administrasi perpajakan adalah kegiatan penatausahaan dan pelayanan yang dilakukan oleh setiap orang yang ada di dalam organisasi demi melaksanakan hak serta kewajiban di bidang perpajakan. Jadi sistem administrasi perpajakan modern adalah program pengembangan dalam perpajakan terutama pada bidang administrasi yang dilakukan oleh instansi yang bersangkutan guna memaksimalkan penerimaan pajak di negara tersebut.

Menurut Rahayu (2013) sistem administrasi perpajakan modern dilingkungan DJP bertujuan untuk menerapkan Good Governance dan pelayanan prima kepada masyarakat. Hal-hal yang mengindikasikan efektivitas sistem perpajakan online yang 
dapat dirasakan oleh wajib pajak antara lain yaitu: E-Registration, E-Billing, E-Filling dan E-Faktur. Berbagai macam fasilitas yang akan dibuat oleh Dirjen Pajak tersebut sangat memudahkan wajib pajak dalam menjalankan kewajiban dan tanggung jawabnya sebagai warga negara yang baik dan patuh. Melalui fasilitas E-Billing dan EFilling wajib pajak dapat lebih mudah dalam melaporkan SPT dan membayarkan pajak menggunakan kode Billing.

\section{Kepatuhan Wajib Pajak}

Pemahaman berarti tunduk dan patuh pada ajaran atau suatu aturan normanorma yang ada dan berlaku. Menurut Rahadi (2014), Menyatakan bahwa pengetahuan dan pemahaman pajak berpengaruh positif terhadap kepatuhan wajib pajak. Pemahaman Wajib Pajak tentang peraturan perpajakan merupakan penyebab internal karena berada di bawah kendali wajib pajak sendiri. Tingkat pengetahuan dan pemahaman Wajib Pajak yang berbeda-beda akan mempengaruhi penilaian masingmasing Wajib Pajak untuk berperilaku patuh dalam melaksanakan kewajiban perpajakan. Tingkat pemahaman Wajib Pajak tinggi akan membuat Wajib Pajak memilih berperilaku patuh dalam melaksanakan kewajiban perpajakan.

Menurut Budiartha (2013), Menyatakan bahwa kurangnya upaya Wajib Pajak dalam memperhatikan info-info pemberitahuan atau iklan yang telah dilakukan oleh pihak aparat pajak, membuat Wajib Pajak cenderung tidak patuh dalam membayar kewajiban perpajakan. Wajib Pajak yang akan membayar pajak tentunya perlu memahami manfaat dalam membayar pajak dan fungsi dari pajak itu sendiri. Semakin tingginya pemahaman tentang peraturan perpajakan, maka Wajib Pajak akan semakin patuh dalam membayar pajak.

\section{METODE PENELITIAN}

\section{Jenis Penelitian}

Jenis penelitian ini bersifat Asosiatif. Menurut Ulum et al. (2016) Penelitian asosiatif adalah jenis penelitian yang bertujuan untuk menganalisis hubungan antara suatu variabel dengan variabel yang lain. Hubungan ini dapat berupa hubungan biasa (korelasi), maupun hubungan kausalitas (sebab-akibat). Pendekatan penelitian menggunakan pendekatan kuantitatif, hal tersebut dikarenakan pada penelitian ini peneliti lebih banyak menggunakan data secara numerikal atau angka yang diolah menggunakan bantuan software SPSS dengan menggunakan analisis logistik.

\section{Tempat \& Waktu Penelitian}

Penelitian ini dilakukan terhadap Wajib Pajak yang berada dan bekerja di Kantor PT Bali Jaya Transindo yang berlokasi di Jl. Margomulyo Indah no. 3 Surabaya. Penyebaran hingga terkumpulnya hasil tanggapan atas kuesioner yang telah disebar dilaksanakan mulai tanggal 17 Juni 2019 - 22 Juli 2019.

\section{Populasi, Sampel dan Teknik Pengambilan Sampel}

Menurut Sugiyono (2013:115), Populasi adalah wilayah generalisasi yang terdiri atas obyek atau subyek yang memiliki kualitas dan karakteristik tertentu yang ditentukan oleh peneliti untuk dipelajari dan kemudian diambil kesimpulannya. 
Populasi dalam penelitian ini adalah seluruh wajib pajak orang pribadi yang terdaftar dan efektif yang masih aktif menjalankan kewajiban perpajakannya di lingkungan PT Bali Jaya Transindo.

Menurut Sugiyono (2013:116), Sampel merupakan bagian dari jumlah dan karakteristik yang dimiliki oleh suatu populasi. Pengambilan sampel pada penelitian ini menggunakan teknik Purposive Sampling atau yang disebut sampling non random sampling dimana peneliti menentukan pengambilan sampel dengan cara menetapkan ciri-ciri khusus yang sesuai dengan tujuan penelitian sehingga diharapkan dapat menjawab permasalahan penelitian.

Sampel yang diambil merupakan sampel yang terdata pada Kantor PT Bali Jaya Transindo Surabaya sebanyak 32 Orang wajib pajak. Kriteria sampel penelitian ini adalah :

1. Wajib pajak yang terdaftar

2. Wajib pajak bekerja di PT Bali Jaya Transindo Surabaya

Kemudian peneliti akan memberikan kuesioner kepada sampel penelitian tersebut. Kuesioner dan dokumentasi dalam penelitian ini digunakan sebagai sarana dalam pengumpulan data penelitian.

\section{Teknik Pengumpulan Data}

Data yang dibutuhkan dalam penelitian ini di dapat dari data primer dan data sekunder. Data primer diperoleh melalui penyebaran kuesioner yang diberikan kepada wajib pajak orang pribadi yang menjadi responden penelitian ini. Data sekunder diperoleh melalui studi pustaka dengan mempelajari berbagai hal tulisan yang berhubungan dengan data-data dalam penelitian ini.

Kuesioner adalah suatu teknik pengumpulan data dengan cara memberikan atau menyebarkan berbagai pertanyaan yang diperlukan kepada seluruh responden. Dengan harapan mampu memberikan respon atas daftar-daftar pertanyaan yang telah diajukan. Dalam pengumpulan data diperlukan data koesioner yang langsung dapat diterima oleh seluruh responden dengan cara menyebar kuesioner melalui form google agar lebih efektif dan mudah dalam pelaksanaannya.

\section{Teknik Analisis Data}

Analisis data dalam penelitian merupakan bagian dari proses pengujian data setelah tahap pemilihan dan pengumpulan data dalam sebuah penelitian. Analisis data yang dilakukan adalah Regresi Linear Berganda. Tahapan-tahapan analisis ini meliputi:

1. Uji Validitas

Uji validitas digunakan untuk mengukur sah atau tidaknya suatu kuesioner. Suatu kuesioner akan dikatakan valid apabila pertanyaan dalam kuesioner mampu untuk mengungkapkan sesuatu yang akan diukur oleh kuesioner tersebut (Ghozali. 2013:49).

Dalam hal ini koefisien yang nilai signifikannya lebih kecil dari angka 5\% (level of significance) menunjukkan bahwa pertanyaan-pertanyaan tersebut sudah asli (sahih) sebagai pembentuk indicator. Dasar analisis yang digunakan untuk pengujian validitas sebagai berikut (Ghozali, 2013:53) yaitu: 
Jika nilai sig $>0.05$ maka butir atau variabel tersebut tidak valid;

Jika nila sig < 0.05 maka butir atau variabel tersebut valid;

2. Uji Reliabilitas

Reliabilitas adalah ukuran konsistensi internal dari indikator-indikator sebuah variabel bentukkan yang menunjukkan derajat sampai dimana masingmasing indikator itu mengindikasikan sebuah variabel bentukkan umum. Uji realibilitas digunakan untuk mengukur konsistensi jawaban dari responden, suatu kuesioner dikatakan reliabel jika jawaban seseorang terhadap kuesioner adalah konsisten atau stabil dari waktu ke waktu. Kriteria pengujian dilakukan menggunakan pengujian Cronbach Alpha.

Reliabilitas suatu konstruk variabel dikatakan baik jika memiliki nilai Alpha Cronbach's sebagai berikut:

Alpha Cronbach's > 0.70 - (Ghozali, 2011:147)

\section{Regresi Linear Berganda}

Analisis ini digunakan untuk meramalkan bagaimana keadaan variabel terikat ketika jumlah variabel bebasnya lebih dari 2 (dua), dalam penelitian ini analisis regresi linear berganda digunakan untuk membuktikan sejauh mana hubungan pengaruh sistem administrasi perpajakan modern dan kesadaran wajib pajak terhadap kepatuhan wajib pajak. Dengan kata lain melibatkan 2 (dua) variabel bebas yaitu: $\left(X_{1}, X_{2}\right.$,) dan satu variabel terikat (Y). Regresi linear berganda digunakan apabila variabel independen terdiri dari 2 (dua) atau lebih.

Model regresi yang digunakan adalah:

$$
\mathrm{Y}=\alpha+\beta_{1} \mathrm{X}_{1}+\beta_{2} \mathrm{X}_{2}+\beta_{3} \mathrm{X}_{3}+\mathrm{e}
$$

Keterangan :

$\begin{array}{lll}\mathrm{Y} & = & \text { Variabel Terikat } \\ \alpha & = & \text { Konstanta } \\ \beta_{1}-\beta_{3} & = & \text { Koefisien Regresi } \\ \mathrm{X}_{1}-\mathrm{X}_{3} & = & \text { Variabel Bebas } \\ \mathrm{e} & = & \text { Residual }\end{array}$

\section{HASIL PENELITIAN DAN PEMBAHASAN}

\section{Hasil Penelitian}

\section{Uji Validitas \& Uji Reliabilitas}

1. Uji Validitas

Uji Validitas digunakan untuk mengukur sah atau tidaknya suatu kuesioner. Suatu kuesioner dinyatakan valid jika pernyataan dalam kuesioner mampu untuk menungkapkan sesuatu yang akan diukur untuk kuesioner tersebut (Ghozali, 2013:49). Dalam hal ini koefisien yang nilai signifikannya lebih kecil dari 5\% menunjukkan bahwa pernyataan-pernyataan tersebut sudah sahih sebagai pembentuk indikator. Dasar analisis yang digunakan untuk pengujian validitas sebagai berikut (Ghozali, 2013:3) yaitu : 
Jika sig > 0.05 maka butir atau variabel tersebut tidak valid;

Jika sig $<0.05$ maka butir atau variabel tersebut valid;

Tabel 1. Hasil Uji Validitas Variabel Sistem Administrasi Perpajakan Modern (X1)

\begin{tabular}{|c|c|c|c|c|c|c|}
\hline \multicolumn{7}{|c|}{ Correlations } \\
\hline & & $\mathrm{X} 1.1$ & $\mathrm{X} 1.2$ & $\mathrm{X} 1.3$ & $\mathrm{X} 1.4$ & $\begin{array}{l}\text { TOTAL_ } \\
\mathrm{X} 1\end{array}$ \\
\hline \multirow[t]{3}{*}{$\mathrm{X} 1.1$} & $\begin{array}{l}\text { Pearson } \\
\text { Correlation }\end{array}$ & 1 & ,332 & ,093 &,- 063 & $491^{* *}$ \\
\hline & Sig. (2-tailed) & & ,064 & ,613 &, 731 & ,004 \\
\hline & $\mathrm{N}$ & 32 & 32 & 32 & 32 & 32 \\
\hline \multirow[t]{3}{*}{$\mathrm{X} 1.2$} & $\begin{array}{l}\text { Pearson } \\
\text { Correlation }\end{array}$ & ,332 & 1 &, $555^{* *}$ & ,081 &, $749^{* *}$ \\
\hline & Sig. (2-tailed) & ,064 & & ,001 & ,659 & ,000 \\
\hline & $\mathrm{N}$ & 32 & 32 & 32 & 32 & 32 \\
\hline \multirow[t]{3}{*}{$\mathrm{X} 1.3$} & $\begin{array}{l}\text { Pearson } \\
\text { Correlation }\end{array}$ & ,093 &, $555^{* *}$ & 1 &, $414^{*}$ &, $799^{* *}$ \\
\hline & Sig. (2-tailed) & ,613 & ,001 & & ,019 & ,000 \\
\hline & $\mathrm{N}$ & 32 & 32 & 32 & 32 & 32 \\
\hline \multirow[t]{3}{*}{$\mathrm{X} 1.4$} & $\begin{array}{l}\text { Pearson } \\
\text { Correlation }\end{array}$ &,- 063 & ,081 &, $414^{*}$ & 1 &, $572^{* *}$ \\
\hline & Sig. (2-tailed) & ,731 & ,659 & ,019 & & ,001 \\
\hline & $\mathrm{N}$ & 32 & 32 & 32 & 32 & 32 \\
\hline \multirow[t]{3}{*}{$\begin{array}{l}\text { TOTAL_ } \\
\text { X1 }\end{array}$} & $\begin{array}{l}\text { Pearson } \\
\text { Correlation }\end{array}$ & ,491 &, $749^{* *}$ &, $799^{* *}$ &, $572^{* *}$ & 1 \\
\hline & Sig. (2-tailed) & ,004 & ,000 &, 000 & ,001 & \\
\hline & $\mathrm{N}$ & 32 & 32 & 32 & 32 & 32 \\
\hline
\end{tabular}

Sumber : Hasil Penelitian, diolah (2019)

Dari hasil uji SPSS v.20 Tabel 1 diatas menunjukkan bahwa setiap variabel Sistem Administrasi Perpajakan Modern mempunyai kriteria valid pada setiap item pernyataan dengan nilai signifikansi sebesar X1.1 =0,004; X1.2 =0,000; X1.3 = 0,$000 ; \mathrm{X} 1.4=0,001$ yang artinya nilai signifikansi pada setiap item pernyataan kurang dari $<0,05$ sehingga semua butir pernyataan maupun indikator Sistem Administrasi Perpajakan Modern dinyatakan valid. 
Tabel 2. Hasil Uji Validitas Variabel Kesadaran Wajib Pajak (X2)

\begin{tabular}{|c|c|c|c|c|c|c|}
\hline \multicolumn{7}{|c|}{ Correlations } \\
\hline & & $\mathrm{X} 2.1$ & $\mathrm{X} 2.2$ & X2.3 & X2.4 & $\begin{array}{l}\text { TOTAL } \\
\text { X2 }\end{array}$ \\
\hline \multirow[t]{3}{*}{$\mathrm{X} 2.1$} & $\begin{array}{l}\text { Pearson } \\
\text { Correlation }\end{array}$ & 1 &, $555^{* *}$ &,- 017 & ,076 &, $580^{* * *}$ \\
\hline & Sig. (2-tailed) & &, 001 & ,928 & ,681 & ,001 \\
\hline & $\mathrm{N}$ & 32 & 32 & 32 & 32 & 32 \\
\hline \multirow[t]{3}{*}{$\mathrm{X} 2.2$} & $\begin{array}{l}\text { Pearson } \\
\text { Correlation }\end{array}$ &, $555^{* *}$ & 1 &, $442^{*}$ & 240 &, $851^{* *}$ \\
\hline & Sig. (2-tailed) &, 001 & &, 011 &, 186 &, 000 \\
\hline & $\mathrm{N}$ & 32 & 32 & 32 & 32 & 32 \\
\hline \multirow[t]{3}{*}{$\mathrm{X} 2.3$} & $\begin{array}{l}\text { Pearson } \\
\text { Correlation }\end{array}$ &,- 017 &, $442^{*}$ & 1 &,- 013 &, $580^{* *}$ \\
\hline & Sig. (2-tailed) & ,928 & ,011 & & ,942 & ,001 \\
\hline & $\mathrm{N}$ & 32 & 32 & 32 & 32 & 32 \\
\hline \multirow[t]{3}{*}{$\mathrm{X} 2.4$} & $\begin{array}{l}\text { Pearson } \\
\text { Correlation }\end{array}$ & ,076 & ,240 &,- 013 & 1 &, $545^{* *}$ \\
\hline & Sig. (2-tailed) & ,681 & , 186 & ,942 & & ,001 \\
\hline & $\mathrm{N}$ & 32 & 32 & 32 & 32 & 32 \\
\hline \multirow[t]{3}{*}{$\begin{array}{l}\text { TOTAL_ } \\
\text { X2 }\end{array}$} & $\begin{array}{l}\text { Pearson } \\
\text { Correlation }\end{array}$ &, $580^{* *}$ &, $851^{* *}$ &, $580^{* *}$ &, $545^{* *}$ & 1 \\
\hline & Sig. (2-tailed) &, 001 &, 000 &, 001 & ,001 & \\
\hline & $\mathrm{N}$ & 32 & 32 & 32 & 32 & 32 \\
\hline
\end{tabular}

Sumber : Hasil Penelitian, diolah (2019)

Dari hasil uji SPSS v.20 Tabel 2 diatas menunjukkan bahwa setiap variabel Kesadaran Wajib Pajak mempunyai kriteria valid pada setiap item pernyataan dengan nilai signifikansi sebesar X2.1 $=0,001 ; \mathrm{X} 2.2=0,000 ; \mathrm{X} 2.3=0,001 ; \mathrm{X} 2.4=0,001$ yang artinya nilai signifikansi pada setiap item pernyataan kurang dari $<0,05$ sehingga semua butir pernyataan maupun indikator Sistem Administrasi Perpajakan Modern dinyatakan valid.

Tabel 3. Hasil Uji Validitas Variabel Kepatuhan Wajib Pajak (Y)

\begin{tabular}{|l|l|l|l|l|l|l|}
\hline \multicolumn{2}{|c|}{} & Y1 & Y2 & Y3 & Y4 & $\begin{array}{l}\text { TOTAL } \\
\text { Y }\end{array}$ \\
\hline \multirow{2}{*}{ Y1 } & Pearson Correlation & 1 &, 108 &,- 011 &, 066 &, $504^{* *}$ \\
\cline { 2 - 7 } & Sig. (2-tailed) & &, 555 &, 954 &, 721 & $\mathbf{, 0 0 3}$ \\
\cline { 2 - 7 } & N & 32 & 32 & 32 & 32 & 32 \\
\hline \multirow{3}{*}{ Y2 } & Pearson Correlation &, 108 & 1 &, 348 &, 329 &, $750^{* *}$ \\
\cline { 2 - 7 } & Sig. (2-tailed) &, 555 & &, 051 &, 066 &, $\mathbf{0 0 0}$ \\
\cline { 2 - 7 } & N & 32 & 32 & 32 & 32 & 32 \\
\hline
\end{tabular}


Lanjutan Tabel 3. Hasil Uji Validitas Variabel Kepatuhan Wajib Pajak (Y)

\begin{tabular}{|l|l|l|l|l|l|l|}
\hline \multicolumn{7}{|c|}{ Correlations } \\
\hline \multirow{2}{*}{} & & Y1 & Y2 & Y3 & Y4 & $\begin{array}{c}\text { TOTAL } \\
\text { Y }\end{array}$ \\
\hline \multirow{4}{*}{ Y3 } & Pearson Correlation &,- 011 &, 348 & 1 &, 000 &, $499^{* *}$ \\
\cline { 2 - 7 } & Sig. (2-tailed) &, 954 &, 051 & & 1,000 & $\mathbf{, 0 0 4}$ \\
\cline { 2 - 7 } & $\mathrm{N}$ & 32 & 32 & 32 & 32 & 32 \\
\hline \multirow{4}{*}{ Y4 } & Pearson Correlation &, 066 &, 329 &, 000 & 1 &, $624^{* *}$ \\
\cline { 2 - 7 } & Sig. (2-tailed) &, 721 &, 066 & 1,000 & & $\mathbf{, 0 0 0}$ \\
\cline { 2 - 7 } & $\mathrm{N}$ & 32 & 32 & 32 & 32 & 32 \\
\hline \multirow{2}{*}{$\begin{array}{l}\text { TOTAL } \\
\text { _Y }\end{array}$} & Pearson Correlation &, $504^{* *}$ &, $750^{* *}$ &, $499^{* *}$ &, $624^{* *}$ & 1 \\
\cline { 2 - 7 } & Sig. (2-tailed) &, 003 &, 000 &, 004 &, 000 & \\
\cline { 2 - 7 } & $\mathrm{N}$ & 32 & 32 & 32 & 32 & 32 \\
\hline \multirow{2}{*}{$* *$ Correlation is significant at the 0.01 level (2-tailed). } & & \\
\hline
\end{tabular}

Sumber : Hasil Penelitian, diolah (2019)

Dari hasil uji SPSS v.20 Tabel 3 diatas menunjukkan bahwa setiap variabel Kepatuhan Wajib Pajak mempunyai kriteria valid pada setiap item pernyataan dengan nilai signifikansi sebesar $\mathrm{Y} 1=0,003 ; \mathrm{Y} 2=0,000 ; \mathrm{Y} 3=0,004 ; \mathrm{Y} 4=0,000$ yang artinya nilai signifikansi pada setiap item pernyataan kurang dari $<0,05$ sehingga semua butir pernyataan maupun indikator Sistem Administrasi Perpajakan Modern dinyatakan valid.

\section{Uji Reliabilitas}

Reliabilitas adalah ukuran konsistensi internal dari indikator-indikator sebuah variabel bentukkan yang menunjukkan derajat sampai dimana masing-masing indikator itu mengindikasikan sebuah variabel bentukkan umum. Uji realibilitas digunakan untuk mengukur konsistensi jawaban dari responden, suatu kuesioner dikatakan reliabel jika jawaban seseorang terhadap kuesioner adalah konsisten atau stabil dari waktu ke waktu. Kriteria pengujian dilakukan menggunakan pengujian Cronbach Alpha.

Reliabilitas suatu konstruk variabel dikatakan baik jika memiliki nilai Alpha Cronbach's sebagai berikut:

Alpha Cronbach's > 0.70 - (Ghozali, 2011:147)

\section{Tabel 4. Hasil Uji Reliabilitas Var. Sistem Administrasi Perpajakan Modern (X1) Reliability Statistics}

\begin{tabular}{|l|l|}
\hline $\begin{array}{l}\text { Cronbach's } \\
\text { Alpha }\end{array}$ & N of Items \\
\hline $\mathbf{7 5 5}$ & 5 \\
\hline
\end{tabular}

Sumber : Hasil Penelitian, diolah (2019)

Dari hasil uji SPSS v.20 Tabel 4 diatas diketahui bahwa nilai Alpha Cronbach's dari variabel Sistem Administrasi Perpajakan Modern adalah sebesar 
0,755. Dengan demikian dapat disimpulkan bahwa item pernyataan ataupun indikator dalam koesioner Sistem Administrasi Perpajakan Modern ini Reliabel dikarenakan hasil nilai Alpha Cronbach's lebih besar dari 0,70.

Tabel 5. Hasil Uji Reliabilitas Variabel Kesadaran Wajib Pajak (X2)

\section{Reliability Statistics}

\begin{tabular}{|l|l|}
\hline $\begin{array}{l}\text { Cronbach's } \\
\text { Alpha }\end{array}$ & N of Items \\
\hline ,739 & 5 \\
\hline
\end{tabular}

Sumber : Hasil Penelitian, diolah (2019)

Dari hasil uji SPSS v.20 Tabel 5 diatas diketahui bahwa hasil nilai Alpha Cronbach's dari variabel Kesadaran Wajib Pajak adalah sebesar 0,739. Dengan demikian dapat disimpulkan bahwa pernyataan maupun indikator dalam koesioner Kesadaran Wajib Pajak ini Reliabel karena nilai Alpha Cronbach's lebih besar dari 0,70 .

\section{Tabel 6. Hasil Uji Reliabilitas Variabel Kepatuhan Wajib Pajak (Y)} Reliability Statistics

\begin{tabular}{|l|l|}
\hline $\begin{array}{l}\text { Cronbach's } \\
\text { Alpha }\end{array}$ & N of Items \\
\hline, 718 & 5 \\
\hline
\end{tabular}

Sumber : Hasil Penelitian, diolah (2019)

Dari hasil uji SPSS v.20 Tabel 6 diatas diketahui bahwa nilai Alpha Cronbach's dari variabel Kepatuhan wajib pajak adalah sebesar 0,718. Dengan demikian dapat disimpulkan bahwa pernyataan maupun indikator dalam koesioner Kepatuhan Wajib Pajak ini Reliabel karena nilai Alpha Cronbach's lebih besar dari 0,70 .

\section{Analisis Regresi Linear Berganda}

Uji regresi berganda dilakukan untuk memprediksi apakah dua variabel atau lebih variabel $\mathrm{X}$ berpengaruh terhadap variabel $\mathrm{Y}$ dan seberapa besar pengaruh kedua variabel bebas $(\mathrm{X})$ terhadap variabel terikat $(\mathrm{Y})$.

Jika sig > 0.05 maka butir atau variabel tersebut tidak valid;

Jika sig < 0.05 maka butir atau variabel tersebut valid; 
Tabel 7. Hasil Uji Regresi Linier Berganda

\begin{tabular}{|c|c|c|c|c|c|c|}
\hline \multicolumn{7}{|c|}{ Coefficients $^{\mathbf{a}}$} \\
\hline \multirow{2}{*}{\multicolumn{2}{|c|}{ Model }} & \multicolumn{2}{|c|}{$\begin{array}{c}\text { Unstandardized } \\
\text { Coefficients }\end{array}$} & \multirow{2}{*}{\begin{tabular}{|l|}
$\begin{array}{c}\text { Standardized } \\
\text { Coefficients }\end{array}$ \\
Beta \\
\end{tabular}} & \multirow[t]{2}{*}{$\mathbf{t}$} & \multirow[t]{2}{*}{ Sig. } \\
\hline & & $\mathrm{B}$ & Std. Error & & & \\
\hline \multirow[t]{3}{*}{1} & (Constant) & 2,049 & 1,160 & & 1,767 & ,088 \\
\hline & $\begin{array}{l}\text { Sistem Administrasi } \\
\text { Perpajakan Modern }\end{array}$ & ,003 & , 040 & ,005 & ,062 & ,951 \\
\hline & Kesadaran WP & ,869 & ,081 & ,906 & $\begin{array}{l}10,77 \\
4\end{array}$ & ,000 \\
\hline
\end{tabular}

Sumber : Hasil Penelitian, diolah (2019)

Berdasarkan Tabel 8 diatas maka dapat dibentuk persamaan regresi :

$\mathrm{Y}=\mathrm{a}+\mathrm{bX} 1+\mathrm{bX} 2+\mathrm{e}$

$\mathrm{Y}=2,049+0,003+0,869+\mathrm{e}$

Dari persamaan regresi tersebut menunjukkan bahwa variabel Sistem

Administrasi Perpajakan Modern (X1), dan Kesadaran Wajib Pajak (X2) memiliki nilai koefisien (Constant) Positif. Sehingga dapat disimpulkan jika variabel Sistem Administrasi Perpajakan Modern dan Kesadaran Wajib Pajak meningkat, maka Kepatuhan wajib pajak juga akan meningkat.

\section{Pengaruh Sistem Administrasi Perpajakan Modern Terhadap Kepatuhan Wajib Pajak}

Berdasarkan tabel 7 diatas diketahui bahwa nilai signifikansi Sistem administrasi (X1) adalah sebesar 0,951 lebih besar dari > 0,05 maka Hipotesis Ho diterima dan Ha ditolak. Artinya secara parsial variabel Sistem administrasi perpajakan modern (X1) tidak berpengaruh terhadap variabel Kepatuhan wajib pajak (Y).

\section{Pengaruh Kesadaran Wajib Pajak Terhadap Kepatuhan Wajib Pajak}

Berdasarkan tabel 7 diatas diketahui bahwa nilai signifikansi Kesadaran wajib pajak (X2) adalah sebesar 0,000 lebih kecil dari < 0,05 maka Hipotesis Ho ditolak dan Ha diterima. Artinya secara parsial variabel Kesadaran wajib pajak (X2) berpengaruh terhadap variabel Kepatuhan wajib pajak (Y).

\section{Uji F}

Uji $\mathrm{F}$ bertujuan untuk mengetahui ada atau tidaknya pengaruh simultan (bersama-sama) yang diberikan variabel bebas (X) terhadap variabel (Y). Uji $\mathrm{F}$ digunakan untuk menguji kelayakan model dalam analisis regresi. Dalam penelitian ini, hipotesis yang digunakan adalah :

Ho : Variabel-variabel independen (X) tidak mempunyai pengaruh yang signifikan secara bersama-sama terhadap variabel dependen $(\mathrm{Y})$.

Ha : Variabel-variabel independen (X) mempunyai pengaruh yang signifikan secara bersama-sama terhadap variabel dependen $(\mathrm{Y})$. 
Menurut Ghozali (2011) menyatakan bahwa dasar pengambilan keputusannya adalah dengan menggunakan angka probabilitas signifikansi, yaitu :

1. Apabila probabilitas signifikansi > 0.05 maka Ho diterima dan Ha ditolak. Yang berarti ada perbedaan yang signifikan antara model dengan nilai observasinya sehingga model penelitian belum tepat.

2. Apabila probabilitas signifikansi $<0.05$ maka Ho ditolak dan Ha diterima. Yang berarti model mampu memprediksi nilai observasinya sehingga model penelitian sudah tepat.

\section{Pembahasan}

\section{Pengaruh Sistem Administrasi Perpajakan Modern Terhadap Kepatuhan Wajib Pajak}

Variabel sistem administrasi perpajakan modern $\left(\mathrm{X}_{1}\right)$ tidak berpengaruh terhadap kepatuhan wajib pajak (Y). Berdasarkan hasil uji $\mathrm{T}$ nilai signifikansi untuk sistem administrasi perpajakan modern $\left(\mathrm{X}_{1}\right)$ terhadap kepatuhan wajib pajak (Y) adalah sebesar 0,951>0,05 sehingga dapat disimpulkan bahwa tidak terdapat pengaruh sistem administrasi perpajakan modern $\left(\mathrm{X}_{1}\right)$ terhadap kepatuhan wajib pajak (Y).

Hasil penelitian ini mendukung hasil penelitian yang dilakukan oleh W.K Sarunan (2015) yang membuktikan bahwa sistem administrasi perpajakan modern tidak berpengaruh signifikan terhadap variabel kepatuhan wajib pajak. Hasil ini didukung oleh jawaban responden dimana mereka sebagian besar menjawab pada pernyataan "Pelaporan pajak melalui $e-S P T$ dan $e$-Filling sangat efektif" mayoritas responden sebesar 24 atau 70,6\% menjawab sangat setuju (SS) dan 8 atau 29,4\% menjawab setuju (S).

Pada pernyataan "NPWP berfungsi sebagai identitas bagi wajib pajak" mayoritas responden sebesar 27 atau 73,5\% menjawab sangat setuju (SS) dan 5 atau 26,5 menjawab setuju (S).

Pada pernyataan "Pendaftaran NPWP melalui e-Registration lebih mudah" mayoritas responden sebesar 24 atau 70,6\% menjawab sangat setuju (SS) dan 8 atau 29,4\% menjawab setuju (S).

Pada pernyataan "Direktorat jenderal pajak selalu mensosialisasikan jika terjadi adanya perubahan peraturan" mayoritas responden sebesar 12 atau 44,1\% menjawab sangat setuju (SS) dan 20 atau 55,9\% menjawab setuju (S).

\section{Pengaruh Kesadaran Wajib Pajak Terhadap Kepatuhan Wajib Pajak}

Variabel kesadaran wajib pajak $\left(\mathrm{X}_{2}\right)$ berpengaruh positif terhadap kepatuhan wajib pajak (Y). Berdasarkan hasil uji T nilai signifikansi untuk kesadaran wajib pajak $\left(\mathrm{X}_{2}\right)$ terhadap kepatuhan wajib pajak $(\mathrm{Y})$ adalah sebesar $0,000<0,05$ sehingga dapat disimpulkan bahwa terdapat pengaruh kesadaran wajib pajak $\left(\mathrm{X}_{2}\right)$ terhadap kepatuhan wajib pajak (Y).

Hasil penelitian ini mendukung hasil penelitian yang dilakukan oleh Adhitya Febrian Arifin (2015) yang menyatakan bahwa variabel kesadaran wajib pajak berpengaruh positif terhadap kepatuhan wajib pajak. Hal ini didukung oleh jawaban responden dimana mereka sebagian besar menjawab pada pernyataan "Saya 
menghitung, melaporkan dan membayar pajak atas kesadaran diri sendiri" mayoritas responden sebesar 22 atau 52,9\% menjawab sangat setuju (SS) dan 10 atau 47,1\% menjawab setuju (S).

Pada pernyataan "Membayar pajak merupakan kewajiban" mayoritas responden sebesar 19 atau 64,7\% menjawab sangat setuju (SS) dan 13 atau 35,3\% menjawab setuju (S).

Pada pernyataan "Membayar pajak merupakan bentuk bantuan untuk membangun negara" mayoritas responden sebesar 19 atau $64,7 \%$ menjawab sangat setuju (SS) dan 13 atau 35,3\% menjawab setuju (S).

Pada pernyataan "Membayar pajak tidak sesuai dapat merugikan negara" mayoritas responden sebesar 17 atau 57,6\% menjawab sangat setuju (SS) dan 15 atau 42,4\% menjawab setuju (S).

\section{Pengaruh Penerapan Sistem Administrasi Perpajakan Modern Dan Kesadaran Wajib Pajak Terhadap Kepatuhan Wajib Pajak}

Variabel Sistem administrasi perpajakan modern (X1) dan Kesadaran wajib pajak (X2) berpengaruh positif terhadap Kepatuhan wajib pajak (Y). Hal ini dapat dilihat dari nilai koefisien regresi yang bernilai positif yaitu $0,003: 0,869$ artinya secara simultan (bersama-sama) variabel independen berpengaruh signifikan terhadap variabel dependen. Berdasarkan hasil Uji Determinasi (R2 diketahui nilai R Square adalah sebesar 0,824. Hal ini berarti bahwa pengaruh variabel Sistem administrasi perpajakan modern (X1) dan Kesadaran wajib pajak (X2) secara simultan terhadap variabel Kepatuhan wajib pajak (Y) adalah sebesar 82,4\%. Berdasarkan hasil uji $\mathrm{F}$ nilai signifikansi untuk Sistem administrasi perpajakan modern (X1) dan Kesadaran wajib pajak (X2) secara simultan terhadap Kepatuhan wajib pajak (Y) adalah sebesar $0,000<0,05$ sehingga dapat disimpulkan bahwa Ha diterima yang artinya terdapat pengaruh X1 dan X2 secara simultan terhadap Y.

\section{KESIMPULAN DAN SARAN \\ Kesimpulan}

Penelitian ini bertujuan untuk mengetahui pengaruh variabel sistem administrasi perpajakan modern dan kesadaran wajib pajak terhadap kepatuhan wajib pajak orang pribadi di kantor PT Bali Jaya Transindo.

Berdasarkan hasil analisis yang telah dilakukan, maka simpulan yang dapat diambil dari penelitian ini adalah sebagai berikut :

1. Tidak adanya pengaruh variabel Sistem administrasi perpajakan modern terhadap kepatuhan wajib pajak di kantor PT Bali Jaya Transindo.

2. Adanya pengaruh variabel Kesadaran wajib pajak terhadap Kepatuhan wajib pajak di kantor PT Bali Jaya Transindo.

3. Adanya pengaruh Sistem administrasi perpajakan modern dan Kesadaran wajib pajak secara simultan terhadap Kepatuhan wajib pajak. 


\section{Saran}

Berdasarkan hasil penelitian dan kesimpulan, maka saran-saran yang dapat diberikan berkaitan dengan judul penelitian adalah sebagai berikut :

1. Dari penelitian ini bisa dijadikan sebagai cerminan bagi para wajib pajak untuk menjadi wajib pajak yang patuh terhadap ketentuan umum perpajakan.

2. Dengan adanya Sistem administrasi perpajakan modern yang telah dikembangkan oleh Direktorat Jenderal Pajak (DJP) harusnya dapat menjadikan wajib pajak lebih patuh dalam menjalankan kewajibannya.

3. Perlu adanya penelitian lebih lanjut untuk dapat mengembangkan penelitian ini dan sebelum-sebelumnya dengan menggunakan variabel-variabel lain yang dapat mempengaruhi kepatuhan wajib pajak yang tidak dapat disebutkan dalam penelitian ini.

\section{DAFTAR PUSTAKA}

Arifin Adhitya Febrian. 2015. Pengaruh Modernisasi Sistem Administrasi Perpajakan, Sanksi Pajak dan Pelayanan Fiskus Terhadap Kepatuhan Wajib Pajak Orang Pribadi KPP Pratama. Perbanas Review.

Astana dan Merkusiwati. 2017. Pengaruh Penerapan Sistem Administrasi Perpajakan Terhadap Kepatuhan Wajib Pajak. E-Jurnal Akuntansi.

Diah Sulistia Arini dan Isharijadi. 2015. Pengaruh Penerapan Modernisasi Sistem Administrasi Perpajakan Meliputi Struktur Organisasi, Business Process, dan TIK Terhadap Kepatuhan Wajib Pajak Orang Pribadi Pada Kantor Pelayanan Pajak Pratama Madiun. Assets : E-Jurnal Akuntansi dan Pendidikan.

Ghozali. 2013. Aplikasi Analisis Multivariate dengan Program IBM SPSS20. Semarang: Badan Penerbit Universitas Diponegoro.

Mardiasmo. 2013. Perpajakan Edisi Revisi. Andi Offset, Yogyakart.

Mardiasmo. 2016. "Perpajakan”, Edisi Terbaru, C.V Andi Offet, Yogyakarta.

Pandiangan. 2013. Modernisasi dan Reformasi Pelayanan Perpajakan. Jakarta.

Rahayu, Sri dan Ita Salsalina Lingga. 2009. "Pengaruh Modernisasi Sistem Administrasi Perpajakan terhadap Kepatuhan Wajib Pajak”. Jurnal Akuntansi Vol.1 No.2 November 2009:119-138.

Sugiyono. 2013. "Metode Penelitian Pendidikan Kuantitatif Kualitatif dan R\&D". Bandung: Alfabeta.

Ulum dan Juanda. 2016. Metodologi Penelitian Akuntansi Klinik Skripsi. Malang: Aditya Media Publishing.

Waluyo. 2013. Perpajakan Indonesia. Jakarta: Salemba Empat. 